\title{
Immune gene expression and genome-wide association analysis in rainbow trout with different resistance to Yersinia ruckeri infection
}

Zuo, Shaozhi; Karami, Asma M.; Ødegård, Jørgen; Mathiessen, Heidi; Marana, Moonika H.; Jaafar, Rzgar M.; von Gersdorff Jørgensen, Louise; Abdu, Mohammad; Kania, Per W.; Dalsgaard, Inger

Total number of authors:

12

Published in:

Fish and Shellfish Immunology

Link to article, DOI:

10.1016/j.fsi.2020.07.023

Publication date:

2020

Document Version

Peer reviewed version

Link back to DTU Orbit

Citation (APA):

Zuo, S., Karami, A. M., Ødegård, J., Mathiessen, H., Marana, M. H., Jaafar, R. M., von Gersdorff Jørgensen, L., Abdu, M., Kania, P. W., Dalsgaard, I., Nielsen, T., \& Buchmann, K. (2020). Immune gene expression and genome-wide association analysis in rainbow trout with different resistance to Yersinia ruckeri infection. Fish and Shellfish Immunology, 106, 441-450. https://doi.org/10.1016/j.fsi.2020.07.023

\section{General rights}

Copyright and moral rights for the publications made accessible in the public portal are retained by the authors and/or other copyright owners and it is a condition of accessing publications that users recognise and abide by the legal requirements associated with these rights.

- Users may download and print one copy of any publication from the public portal for the purpose of private study or research.

- You may not further distribute the material or use it for any profit-making activity or commercial gain

- You may freely distribute the URL identifying the publication in the public portal 


\section{Journal Pre-proof}

Immune gene expression and genome-wide association analysis in rainbow trout with different resistance to Yersinia ruckeri infection

Shaozhi Zuo, Asma M. Karami, Jørgen Ødegård, Heidi Mathiessen, Moonika H. Marana, Rzgar M. Jaafar, Louise von Gersdorff Jørgensen, Mohammad Abdu, Per W.

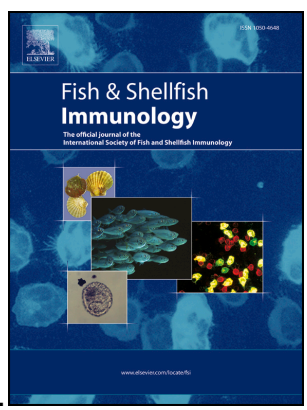
Kania, Inger Dalsgaard, Torben Nielsen, Kurt Buchmann

PII:

$$
\text { S1050-4648(20)30507-6 }
$$

DOI:

$$
\text { https://doi.org/10.1016/j.fsi.2020.07.023 }
$$

Reference: $\quad$ YFSIM 7175

To appear in: $\quad$ Fish and Shellfish Immunology

Received Date: 20 April 2020

Revised Date: 7 July 2020

Accepted Date: 12 July 2020

Please cite this article as: Zuo S, Karami AM, Ødegård Jø, Mathiessen $\mathrm{H}$, Marana $\mathrm{MH}$, Jaafar RM, von Gersdorff Jørgensen L, Abdu M, Kania PW, Dalsgaard I, Nielsen T, Buchmann K, Immune gene expression and genome-wide association analysis in rainbow trout with different resistance to Yersinia ruckeri infection, Fish and Shellfish Immunology (2020), doi: https://doi.org/10.1016/j.fsi.2020.07.023.

This is a PDF file of an article that has undergone enhancements after acceptance, such as the addition of a cover page and metadata, and formatting for readability, but it is not yet the definitive version of record. This version will undergo additional copyediting, typesetting and review before it is published in its final form, but we are providing this version to give early visibility of the article. Please note that, during the production process, errors may be discovered which could affect the content, and all legal disclaimers that apply to the journal pertain.

(C) 2020 Published by Elsevier Ltd. 
Author's contributions

Shaozhi Zuo, Asma M. Karami, Rzgar M. Jaafar, Moonika H. Marana, Kurt Buchmann and Heidi Mathiessen infected the fish and performed sampling. Shaozhi Zuo and Asma M. Karami performed the molecular work, Jørgen $\varnothing$ degård analysed the DNA typing results, Torben Nielsen and Kurt Buchmann designed the experiments and produced the experimental fish, Per W. Kania assisted the qPCR analysis, Inger Dalsgaard produced the bacterial solutions used for challenge, Louise von Gersdorff Jørgensen and Mohammad Abdu contributed to the survey of fish health, Asma M. Karami and Kurt Buchmann wrote the manuscript. 


\title{
Immune gene expression and genome-wide association analysis in rainbow trout with different resistance to Yersinia ruckeri infection
}

\author{
Shaozhi Zuo a , Asma M. Karami ${ }^{\text {**, Jørgen Ødegård }}{ }^{\text {d }}$, Heidi Mathiessen ${ }^{a}$, Moonika H. \\ Marana $^{a}$, Rzgar M. Jaafar ${ }^{\mathrm{a}}$, Louise von Gersdorff Jørgensen ${ }^{\mathrm{a}}$, Mohammad Abdu ${ }^{\mathrm{a}}$, Per W. \\ Kania $^{a}$, Inger Dalsgaard ${ }^{b}$, Torben Nielsen ${ }^{c}, K_{\text {Kurt Buchmann }}{ }^{\text {a }}$ \\ ${ }^{a}$ Department of Veterinary and Animal Sciences, Faculty of Health and Medical Sciences, \\ University of Copenhagen, Frederiksberg C., Denmark \\ ${ }^{b}$ Institute of Aquatic Resources, Technical University of Denmark, Kgs. Lyngby, Denmark \\ ${ }^{c}$ Aquasearch ova ApS, Jelling, Denmark \\ ${ }^{d}$ Aquagen, Norway
}

\begin{abstract}
Selective breeding programmes involving marker assisted selection of innately pathogen resistant strains of rainbow trout rely on reliable controlled infection studies, extensive DNA typing of individual fish and recording of expression of relevant genes. We exposed juvenile rainbow trout (6 $\mathrm{h}$ bath to $2.6 \times 10^{5} \mathrm{CFU} \mathrm{\textrm {mL } ^ { - 1 }}$ ) to the fish pathogen Yersinia ruckeri serotype O1, biotype 2, eliciting Enteric Red Mouth Disease ERM, and followed the disease progression over 21 days. Cumulative mortality reached $42 \%$ at 12 days post challenge (dpc) after which no disease signs were recorded. All fish were sampled for DNA-typing (50k SNP chip, Affymetrix®) throughout the course of infection when they showed clinical signs of disease (susceptible fish) or at day 21 when fish showed no clinical signs of disease (survivors - resistant fish). Genome-wide association analyses of 1027 trout applying single nucleotide polymorphisms (SNPs) as markers revealed an association between traits (susceptible/resistant) and certain regions of the trout genome. It was indicated that multiple genes are involved in rainbow trout resistance towards ERM whereby it is considered a polygenic trait. A corresponding trout group was kept as non-exposed controls and a comparative expression analysis of central innate and adaptive immune genes in gills, spleen and liver was performed for three fish groups: 1) moribund trout exhibiting clinical signs $7 \mathrm{dpc}$ (CS), 2) exposed fish without clinical signs at the same sampling point (NCS) and 3) surviving fish at 21 dpc
\end{abstract}


(survivors). Immune genes encoding inflammatory cytokines (IL-1 $\beta$, IL-2A, IL-6A, IL-8, IL-10A, IL-12, IL-17A/F2A, IL-17C1, IL-17C2, IL-22, IFN $\gamma, \mathrm{TNF} \alpha$ ), acute phase reactants (SAA, C3, cathelicidins, lysozyme) were expressed differently in CS and NCS fish. Correlation (negative or positive) between expression of genes and bacterial load suggested involvement of immune genes in protection. Down-regulation of adaptive immune genes including IgDm, IgDs, IgT and TCR- $\beta$ was seen primarily in CS and NCS fish whereas survivors showed up-regulation of effector molecule genes such as cathelicidins, complement and lysozyme suggesting their role in clearing the infection. In conclusion, SNP analyses indicated that ERM resistance in rainbow trout is a multi-locus trait. The gene expression in surviving fish suggested that several immune genes are associated with the trait conferring resistance.

Keywords: Selective breeding, heritability, Yersinia ruckeri, Immune gene expressions, Rainbow trout

*Corresponding author, asma@ sund.ku.dk

\section{Introduction}

Aquacultured salmonids suffer worldwide from enteric redmouth disease (ERM) caused by various serotypes of enterobacteria within the species Yersinia ruckeri [1-4]. Apart from applying antibiotic treatments, it is possible to reduce economic losses in aquaculture enterprises by performing strict vaccination programmes comprising immersion vaccination of fry and injection vaccination of juveniles and older fish [5-12]. This approach is based on activation of the adaptive immune system of the fish, but it is laborious and costly. Selective breeding of disease resistant fish is another approach with a high health promoting potential. This is based on detection of individuals with a level of natural resistance to the pathogen and subsequent application of these fish as breeders. The resulting offspring exhibit higher survival and will on a longer time-scale add to improved profitability. Traditional selective breeding programmes are conducted over generations whereby results appear after several years [13,14], whereas marker assisted selection of desirable traits in a fish population may accelerate the process [15-17]. Single nucleotide polymorphisms (SNPs) are abundant markers evenly distributed in the animal genome. This makes them promising tools in genetics and breeding programs. Selective breeding programs can benefit from specific knowledge about markers linked to genes encoding specific traits (QTL, quantitative trait loci). Such a marker assisted selection (MAS) approach may be applied for rainbow trout where fine mapping of QTL can be achieved by use of single nucleotide polymorphisms (SNPs) [18]. When applying high 
resolution genotyping techniques [19] individual fish, resistant to a certain pathogen, can be characterized and selected as parent fish (spawner) with specific gene combinations providing protection. A single gene may in a few cases confer resistance [20] although several genes are expected to be involved in most cases. We aimed to characterize trout with different degrees of disease resistance [13], based on their SNP characteristics, and associate these traits with the level of immune gene expression. Here we present data from our genetic selection experiment using rainbow trout as host and $Y$. ruckeri serotype O1, biotype 2, a pathogen which is currently dominating the ERM outbreaks in Europe [21]. We exposed juvenile rainbow trout to $Y$. ruckeri, followed the disease progression in the fish and subsequently sampled moribund and surviving fish for DNA typing (Affymetrix ${ }^{\circledR}$ analysis). A comparative expression analysis of central immune genes (innate and adaptive) was performed for three fish groups: 1) moribund trout with clinical signs (CS) one week after pathogen exposure 2) exposed trout showing no clinical signs (NCS) at the same time point and 3) surviving trout (late stage of the infection). Time point controls of nonexposed fish taken before and during the course of infection were included.

\section{Materials and methods}

\section{Fish}

Eyed rainbow trout eggs (out-bred population from 60 families) from the certified virus-free Halles $\varnothing$ trout farm, Jutland, Denmark, were transferred to a certified pathogen-free hatchery, Aqua Baltic, in Nexø, Denmark, where they were hatched at $7{ }^{\circ} \mathrm{C}$ within the following 14 days. Trout fry was reared to the juvenile stage at $12-13{ }^{\circ} \mathrm{C}$ and when reaching a body weight of $2-3 \mathrm{~g}$ fish were transferred from the hatchery to the infection facility at the University of Copenhagen. Before infection, head kidney swabs of five randomly selected fish were tested on blood agar plates in order to confirm that the fish were free from bacterial infection [21] and a full parasitological examination confirmed absence of parasites [22]. Fish to be infected $(\mathrm{N}=1050)$ were divided into fourteen $150 \mathrm{~L}$ aerated fish tanks with internal biofilters $\left(20 \mathrm{~L} \mathrm{~min}{ }^{-1}\right.$ EHEIM, Germany) (each containing 75 fish) and acclimated to experimental rearing conditions ( $\mathrm{pH} 7.6$, water temperature 19 ${ }^{\circ} \mathrm{C}$, ammonia $<0.5 \mathrm{mg} / \mathrm{L}$, nitrite absent, nitrate $<50 \mathrm{mg} / \mathrm{L}, 12 \mathrm{~h}$ light/ $12 \mathrm{~h}$ dark cycle) for 14 days prior to initiation of the experiment. During the 14 days acclimation and 21 days experimental infection period, fish were fed daily (INICIO 917, BioMar A/S) at a rate of $1.5 \%$ biomass per day and $30 \%$ of tank water was replenished every day. A total of 450 fish were kept $(6 \times 75$ fish) at the same conditions in a separate pathogen-free room and served as non-exposed control fish.

\section{Ethics and legislation}


Infection procedures were performed under the license 2019-15-0201-01614 obtained from the Experimental Animal Inspectorate, Committee for Experimental Animals, Ministry of Environment and Food, Denmark. Ethical guidelines of the University of Copenhagen were followed securing that fish were monitored every $2^{\text {nd }} \mathrm{h}$ around the clock. Death is not acceptable as a humane endpoint and therefore fish showing clinical signs (loss of equilibrium, irregular swimming, bleedings, discoloration) were taken out and euthanized in an overdose MS222 (tricaine methane sulphonate) (300 mg/L) and recorded as mortality.

\section{Challenge procedure}

Fish in 14 tanks, each with 75 fish (2-3g) in a reduced water volume of $30 \mathrm{~L}$, were exposed to a solution of live Yersinia ruckeri (serotype O1, biotype 2, isolate 100415-1/4) currently the most prevalent type in European fish farms). Culture conditions, growth conditions and estimation of colony forming units (CFU) were previously described by [23]. Briefly, in this study the bacterial culture used was cultivated at $20^{\circ} \mathrm{C}$ for $48 \mathrm{~h}$ reaching a concentration of $3.9 \times 10^{8} \mathrm{CFU} \mathrm{mL}^{-1}$. Each tank was supplied with $200 \mathrm{~mL}$ of the broth which was poured into a tank containing $30 \mathrm{~L}$ water whereby the exposure solution was $2.6 \times 10^{8} \mathrm{CFU} \mathrm{mL}^{-1}\left(2.6 \times 10^{5} \mathrm{CFU} \mathrm{mL}{ }^{-1}\right)$. Fish were kept exposed for $6 \mathrm{~h}$ whereafter the full water volume was re-installed to $150 \mathrm{~L}$. During the subsequent course of infection $30 \%$ of the water volume was replaced daily.

\section{Sampling}

Morbidity: Morbidity (and thereby mortality) was continuously recorded following the exposure procedure at day 1 and until day 21.

Sampling for genotyping: All fish were sampled for DNA-typing throughout the course of infection when they showed disease signs (susceptible fish) or at day 21 (surviving non-diseased resistant fish). A circular tissue piece (diameter $2.75 \mathrm{~mm}$ ) of the tail fin was sampled from each fish when the fish was removed from the tank using a punching scissors (agnthos.se, Sweden). The tissue sample was placed in lysis buffer (Vaxxinova.no) for subsequent DNA purification and genotyping.

Sampling for gene expression: Samples for gene expression (gills, liver and spleen) were taken at day 0 before bacterial exposure. Following exposure samples were taken from non-exposed control fish (20 fish), fish exposed but with no clinical signs (NCS) (20 fish) and moribund fish (exposed and fish with clinical signs (CS)) (20 fish) 7 days post challenge (dpc). At day 21only surviving fish were left for sampling. These were taken together with non-exposed time-point controls. Liver, 
spleen and gill samples were fixed in RNAlater, placed at $4{ }^{\circ} \mathrm{C}$ for $24 \mathrm{~h}$ and subsequently stored at $20{ }^{\circ} \mathrm{C}$ until further processing.

\section{RNA extraction and cDNA synthesis}

RNA extraction and cDNA synthesis were performed according to standard procedures [24]. In brief, samples from fish (gills, liver and spleen) were homogenized ( $2 \mathrm{~min}, 20 \mathrm{~Hz}$; Tissue-lyser II, Qiagen) using a homogenization buffer with 2-mercaptoethanol (Sigma-Aldrich), whereafter RNA was recovered by the GenEluteTM mammalian RNA kit (Sigma-Aldrich). It was necessary to pretreat liver samples $\left(55^{\circ} \mathrm{C}\right.$ for $\left.10 \mathrm{~min}\right)$ using a volume of $600 \mu \mathrm{L}$ proteinase solution $(10 \mu \mathrm{L}$ Proteinase K, >800 mAU [milli activity units] $\mathrm{ml}^{-1}$; Sigma-Aldrich) mixed with $590 \mu \mathrm{L}$ RNase-free water (Invitrogen) before performing the above described RNA extraction method. DNase I (Sigma-Aldrich) treatment removed genomic DNA, and the concentration of RNA in isolated preparations was determined applying a NanoDrop 2000 spectrophotometer (Saveen \& Werner ApS). Quality of RNA was evaluated by electrophoresis (ethidium bromide-stained agarose) (Invitrogen). RNA was kept at $-80{ }^{\circ} \mathrm{C}$ until cDNA synthesis. A total of 15 samples from each experimental group $(2 \times 10)$ was selected, based on quality and quantity of extracted RNA, and subsequently used for cDNA synthesis using a T100 Thermal Cycler (Biorad). Each sample was processed in a $20 \mu \mathrm{L}$ reaction volume using $1000 \mathrm{ng}$ of RNA with Oligo $\mathrm{d}(\mathrm{T}) 16$ primer and MultiScribeTM reverse transcription reagents (Fisher Scientific) $\left(25{ }^{\circ} \mathrm{C}\right.$ for $10 \mathrm{~min}, 37{ }^{\circ} \mathrm{C}$ for 60 $\min , 95^{\circ} \mathrm{C}$ for $\left.5 \mathrm{~min}\right)$. Finally, cDNA $(10 \times$ dilution to $200 \mu \mathrm{L})$ was stored at $-20{ }^{\circ} \mathrm{C}$ until further use.

\section{Quantitative RT- qPCR (qPCR)}

Gene expression analyses were conducted according to standard procedures [24] with a few modifications. In brief, for qPCR we used an AriaMx Real-Time PCR machine (AH diagnostics) and primers and Taq-Man probes developed for rainbow trout immune genes (Table 1). The $Y$. ruckeri infection level was estimated by quantifying the expression of the $Y$. ruckeri glutamine synthetase gene $g \ln A$. We applied primers and probes designed for direct detection of Yersinia ruckeri genomic DNA [38] but validated their use for cDNA. Serial dilutions of a plasmid with the glnA gene was used to provide a standard curve (data not shown). The assay estimates the relative level of the infection by the presence of $Y$. ruckeri glnA transcripts rather than the actual number of bacteria. Dead/inactive bacteria will remain un-detected with this method. Reactions were performed in a volume of $12.5 \mu \mathrm{L}(2.5 \mu \mathrm{L}$ cDNA, $6.25 \mu \mathrm{L}$ Brilliant III Ultra-Fast QPCR Master Mix [Agilent Technologies], $1.0 \mu \mathrm{L}$ primer-probe mixture (forward primer [10 $\mu \mathrm{M}$ ], reverse primer 
$[10 \mu \mathrm{M}]$ and Taq-Man probe $[5 \mu \mathrm{M}])$, and $2.75 \mu \mathrm{L}$ RNase-free water. Reactions were run under the following combination of temperature and process time: $95{ }^{\circ} \mathrm{C}$ for $3 \mathrm{~min}, 40$ cycles of denaturation at $94{ }^{\circ} \mathrm{C}$ for $5 \mathrm{~s}$ with a combined annealing/elongation process at $60{ }^{\circ} \mathrm{C}$ for $15 \mathrm{~s}$. The procedure determined expression of genes encoding immune relevant factors such as interleukins (IL-1 $\beta$, IL2A, IL-4/13A, IL-6A, IL-8 (isoforms A to E), IL-10A, IL-12 $\alpha$ chain, IL-17A/F2A, IL-17C1, IL17C2, IL-22), type II interferon (IFN $\gamma 1$ and IFN $\gamma 2$ ), transforming growth factor $\beta$ (TGF- $\beta 1 \mathrm{a}$ ), tumor necrosis factor $\alpha(\mathrm{TNF} \alpha)$, serum amyloid protein A (SAA), complement factor 3 isoform 3 and 4 (C3-3, C3-4), immunoglobulins (IgM, IgDm, IgT,IgDs), cathelicidin (Cath-1, Cath-2), T cell receptor $\beta(\mathrm{TCR} \beta)$ and lysozyme.

\section{Data analysis}

Cumulative mortality rates were compared by Kaplan-Meier survival analyses (GraphPad Prism version 48.3.1, Bethesda, ML, USA). No significant differences among the 14 replicate tanks were found whereafter data were combined (data not shown). The gene expression was assessed by qPCR using the simplified $2^{-\Delta \Delta \mathrm{Cq}}$ method as all the assays exhibited efficiencies within $100 \% \pm 5 \%$ [39]. Using NormFinder [40] and testing possible combination of reference genes, the average of 3 reference genes (ARP, ELF1 $\alpha$ and $\beta$-actin) was chosen as the internal calibrator for normalization of samples (data not shown).

For gene expression analyses all challenged groups were compared using Student's t-test to nonexposed time point controls. Significant differences were recorded for regulations with a fold change of at least 2 and $\mathrm{p}<0.05$. In the time point control groups less than three fish showed $\mathrm{Cq}$ values for four of the genes and therefore a quantitative assessment was not statistically feasible. In those cases, a qualitative assessment (presence/absence of $\mathrm{Cq}$ value) was used and analyzed with the nonparametric Mann-Whitney test using a probability level of 5\%.

A correlation analysis was performed (Spearman rank correlation test) between level of $Y$. ruckeri transcripts and immune gene expression levels.

For genetic analysis, the susceptibility/survival (Live/Dead) phenotype was analysed using the GCTA software [41], using a genomic animal model for estimation of genetic variance and heritability (GREML). The model was as follows:

$$
\mathbf{y}=\mathbf{X} \boldsymbol{\mu}+\mathbf{g}+\mathbf{e}
$$


where $\mathbf{y}$ is a vector of binary phenotypes (Live/Dead), $\boldsymbol{\mu}$ is a vector of tank effects (with associated incidence matrix $\mathbf{X}), \mathbf{g} \sim N\left(\mathbf{0}, \mathbf{G} \sigma_{g}^{2}\right)$ is a vector of random additive polygenic effects and $\mathbf{e} \sim N\left(\mathbf{0}, \mathbf{I} \sigma_{e}^{2}\right)$ is a vector or random residuals. The matrix $\mathbf{G}$ is the genomic relationship matrix, as defined by VanRaden [42]:

$$
\mathbf{G}=\frac{\mathbf{1}}{\sum 2 p_{i}\left(1-p_{i}\right)} \mathbf{M}^{\prime}
$$

where $\mathbf{M}$ is a centred genotype matrix (one column per locus, one line per individual) and $p_{i}$ is the allele frequency for locus $i$. Subsequently, a similar model was also used for the genome-wide association study (GWAS), accounting for single SNP effects as well as polygenic effects, using the leave-one-chromosome-out option (LMM-LOCO) for the latter. This implies that SNPs from the chromosome currently tested are excluded in computation of the GRM. In general, the SNPs used in the analysis were restricted to those of high genotype quality ("PolyHighRes") and minor allele frequency $>0.01$, resulting in 33,963 SNPs being used in the analysis. A total of 1027 fish of high genotype quality was included in the analysis. A similar analysis was run for time from exposure until diseased (moribund-dead) fish were observed.

\section{Results}

\section{Morbidity/mortality}

The first observation of a moribund fish was recorded at $3 \mathrm{dpc}$ whereafter the occurrence of sick fish increased exponentially until mortalities levelled off and ended at $12 \mathrm{dpc}$. During the following $8 \mathrm{~d}$ observation period, no disease signs were detected. Overall morbidity/mortality was $42 \%$ (Fig. 1). Non-infected controls showed $100 \%$ survival.

\section{Gene expression}

Bacterial load. The bacterial load (estimated by quantifying the expression of the gene encoding the Y. ruckeri glutamine synthetase gene $g \ln A$ ) was significantly higher in CS fish compared to NCS fish. The spleen carried - in all samples - a manifold higher load of Y. ruckeri bacteria compared to gills and liver (Fig. 2). Samples taken from surviving fish at $21 \mathrm{dpc}$ and control fish did not show expression of the bacterial glnA gene in any of the organs. It should be noted that this relative estimation method is based on detection of RNA transcripts. If dead or inactivated bacteria (with no transcription) are present in surviving fish, they will not be detected using the method. 
Immune gene expression. Genes encoding immune relevant molecules were expressed to different degrees (Fig. 3), but they were generally upregulated in spleen, gills and liver in CS fish when compared to non-exposed control fish. High upregulations were seen for genes encoding inflammatory cytokines (IFN $\gamma$, TNF $\alpha$, TGF- $\beta 1 \mathrm{a}$, IL-1 $\beta$, IL-2A, IL-4/13A, IL-6A, IL-8, IL-10A), cytokines IL-12, IL-17A/F2A, IL-17C1, IL-17C2, IL-22) (Fig. 4) and effector molecules Cath-1, Cath-2, SAA, Lysozyme, C3 and IgM, except IgDm, IgDs, IgT and TCR $\beta$ which showed down regulations (Fig. 5).

Correlation between bacterial load and immune gene expression. There were an overall positive correlation between bacterial load and immune gene expression. However, the regulation differed between organs and between groups (Table 2). It is noteworthy that the correlation between the bacterial load and gene expression in NCS fish (but not CS fish) was positive for genes encoding IL-1 $\beta$, IL-8, IL-2A, IL-6A, IL-22, Cath-1 and TGF- $\beta 1 \mathrm{a}$ in spleen and gill. Negative correlations for NCS fish were seen for C3, IgDm, IgDs, IgT and lysozyme in all organs.

Differential expression in organs. Despite a higher bacterial load in spleen, the highest significant expression of immune genes in this organ from CS fish was detected only for genes encoding SAA and Cath-2. For NCS fish, the gene encoding SAA had the highest upregulation in spleen.

The liver carried a lower bacterial burden compared to spleen but in CS fish the liver genes encoding IL-1 $\beta$, IL-4/13A, IL-8, IL-17C1, IL-17C2, IFN $\gamma$, TGF- $\beta 1 \mathrm{a}$, TNF $\alpha$, Cath-2, lysozyme and SAA were upregulated to a higher extent than in spleen.

Gills showed in most cases a lower expression of immune genes but it is noteworthy that CS fish expressed genes encoding IL-2A, IL-22, IgM and Cath-1 to a higher extent than both spleen and liver.

Expression in surviving fish. Fish surviving until end of the experiment without developing clinical signs harboured no or a low bacterial load. The expression of immune genes in these fish showed significant upregulation of IFN $\gamma$ (liver), IL-17C1 (spleen), TNF $\alpha$ (spleen and liver), C3 (spleen), Cath-1 (spleen and liver), Cath-2 (gills, spleen and liver) and lysozyme (liver).

Early expression in NCS fish. NCS fish showed a significantly lower expression compared to CS fish. Still, upregulation was found for inflammatory cytokine genes encoding IL-1 $\beta$, IL-6A, IL-8, IL-10A Cath-1, Cath-2, IFN $\gamma$ (spleen, liver and gill), IL-17C2, TNF $\alpha$, C3 (spleen and liver only), 
IL-22 (spleen only) and effector molecules IgM and lysozyme (gills and liver only). Gene expression data are presented in detail in the supplementary file S1).

Genetic analysis. An analysis of moribund versus live fish was performed. The results are shown in Table 3 , indicating a moderate heritability for moribund/alive $(0.19 \pm 0.05$ on the observed scale and $0.31 \pm 0.08$ on the underlying scale). A Manhattan plot from the GWAS is given in Fig. 6A and B.

The SNP analysis pointed to a largely polygenic background for the resistance, with moderate, but highly significant $(\mathrm{P}=3.23 \mathrm{e}-08)$ heritability (suitable for genomic selection). It was noted that multiple loci cross the threshold of genome-wide significance (4 loci for survival, 7 for time-tomorbidity).

\section{Discussion}

Various approaches are being used to control infectious diseases in aquaculture ranging from. application of medicines (antibiotics, chemotherapeutants) via vaccination to genetic selection of disease resistant strains. Clear indications for associations between susceptibility/resistance to pathogens have been presented for virus such as IHNV [43], IPNV [44] and VHSV [15], against bacteria such as Piscirickettsia salmonis [45] and F. psychrophilum $[16,17,46]$ and against parasites such as Myxobolus cerebralis [47]. In addition, in Atlantic salmon resistance genes against IPNV were described by Moen et al. [20] supporting observations by Reyes-Lopez et al. [48].

The potential for selective breeding of $Y$. ruckeri resistant trout was previously suggested by Henryon et al. [13] and description of quantitative trait loci QTLs for this trait would be a useful tool for fast selection. By the advent of a publicly available SNP genotyping array (product name Affymetrix $\left.{ }^{\circledR}\right)$ it has been possible to analyze a high number of rainbow trout with different traits. The array contains detection abilities for 57,501 SNPs which are well represented throughout the rainbow genome on the 29 rainbow trout chromosomes [49].

The present infection study confirmed a marked genetic variability in an outbred population of rainbow trout. The difference in Y. ruckeri susceptibility was clearly reflected by the fast disease development in $42 \%$ of the fish following bath exposure whereas the $58 \%$ survivors resisted the challenge. A significant heritability was found for survival, and the survivors are thus more likely to carry genes encoding one or more forms of resistance. Disease development was clearly associated with a higher bacterial load as gills, liver and spleen of CS fish carried a manifold higher pathogen burden compared to NCS fish. It was also clear that the spleen carried a manifold higher bacterial 
burden compared to gills and liver - emphasizing spleen as a main organ during immunological responses. The importance of the spleen as a central organ in the host response to $Y$. ruckeri was previously shown $[3,10,11]$ corresponding to its role in responses to other pathogens such as Flavobacterium psychrophilum [16]. The SNP analysis pointed to a largely polygenic background for the resistance, with moderate, but highly significant $(\mathrm{P}=3.23 \mathrm{e}-08)$ heritability. In other words, a trait suitable for genomic selection. Multiple loci cross the threshold of genome-wide significance (4 loci for survival, 7 for time-to-morbidity) and these should be further investigated. In this context, the investigation may benefit from larger sample sizes whereby significant QTL may be identified in these regions. These may then be used to select breeders for production of off-spring with higher ERM resistance. The specific genes responsible for susceptibility/resistance are not described in the present study but the gene expression analysis may elucidate the immune reactions in fish with different level of resistance. The analysis may equally well suggest pathways affected by these traits. Gene expression is not necessarily genetically determined and random environmental effects may contribute to the observed gene expression results. However, it is interesting that our gene expression analysis showed that resistant trout, surviving the entire course of infection, expressed a series of genes related to innate immunity while they kept the infection under control. Effector molecules such as the antimicrobial peptides (cathelicidins associated with clearing bacterial infection) [50], complement and lysozyme were significantly upregulated in one or more organs of the survivors indicating their role in protection against $Y$. ruckeri. The cathelicidins comprise a family of prominent antimicrobial peptides (AMPs) representing an old defense system against microbial invasion [51-53]. The upregulation of IFN $\gamma$, IL-17C1 and TNF $\alpha$ genes may reflect their status as signal molecules and possible activators of the above mentioned down-stream reactions. CS fish which were exposed and rapidly developed clinical signs showed expression of most immune genes except the ones encoding effector molecules IgD, IgT, TCR- $\beta$ and the cytokine IL-10A suggesting a depression of these factors induced by the bacteria. In this context, it should be noted that gene expression previously has been shown to be modulated rapidly depending on dose and challenge route $[54,55]$. Of potential relevance, the lower adaptive immunity observed in this study in spleen tissue might be related to b cell activating factors (baff, tnfsf13b) downregulation which needs further investigations.

NCS fish at $7 \mathrm{dpc}$ showed elevated expression of genes encoding IL-10A suggesting a role of this regulatory cytokine in the delay of disease progression. In the same fish, effector molecules cathelicidin 1 and lysozyme were expressed at the same level as in CS fish - despite having a lower 
bacterial load - suggesting a role in protection. Also the correlation analysis - comparing the bacterial load in relation to immune gene expression - may point to factors controlling infection in NCS fish. A higher bacterial load in spleen was associated with involvement of complement, cathelicidins (1 and 2) and SAA besides a series of cytokines. In gills of NCS fish a high positive correlation was found for effector molecules cathelicidins 1 and 2, $\operatorname{IgM}$ and SAA besides involvement of a series of cytokines. In liver, expression of genes encoding effector molecules cathelicidin 2 and SAA was correlated to the bacterial load.

In conclusion, a significant heritability was estimated for the trait associated with rainbow trout resistance to $Y$. ruckeri infection. However, the resistance is probably a polygenic trait although QTL may be characterized in future studies using larger sample sizes. When analysing immune gene expression in CS fish, NCS fish and surviving fish we recognized some genes encoding effector molecules as interesting for further analysis. Although genes encoding innate immune factors, such as antimicrobial peptides cathelicidins (1 and 2), complement factor C3, serum amyloid protein A (SAA) and lysozyme, were upregulated in all groups exposed to the pathogen the noteworthy regulation in survivors suggests a role in control of $Y$. ruckeri infection in rainbow trout. The importance of genes encoding immunoglobulins $\operatorname{IgD}$ and $\operatorname{IgT}$ is questionable due to their depressed or unregulated state in most exposed groups. Of the adaptive components, IgM and TCR$\beta$ genes were on the other hand active also in surviving fish carrying a bacterial burden.

\section{Funding}

The present study was supported by Innovation Fund Denmark by an investment in the project TECHFISH file no. 8090-00002B.

\section{Author's contributions}

SZ, AMK, RMJ, MHM, KB and HM infected the fish and performed sampling. SZ and AMK performed the molecular work, JØ analysed the DNA typing results, TN and KB designed the experiments and produced the experimental fish, PWK assisted the qPCR analysis, ID produced the bacterial solutions used for challenge, LVGJ and MA contributed to the survey of fish health, AMK and $\mathrm{KB}$ wrote the manuscript.

\section{Declaration of competing interest}

None.

\section{Acknowledgement}


The authors are indebted to the staff members of the Bornholm Salmon Hatchery (Aqua Baltic) Nex $\varnothing$, Bornholm for hatching and rearing rainbow trout for the experiment.

\section{References}

[1] E. Tobback, A. Decostere, K. Hermans, F. Haesebrouck, K. Chiers, Yersinia ruckeri infections in salmonid fish, J. Fish Dis. 30 (2007) 257-268, https://doi.org/10.1111/j.1365-2761.2007.00816.x

[2] R.W.Wheeler, R.L. Davies, I. Dalsgaard, J. Garcia, T.J. Welch, S. Wagley, K.S. Bateman, D.W. Verner-Jeffreys, Yersinia ruckeri biotype 2 isolates from mainland Europe and the UK likely represent different clonal groups, 84 (2009) 25-33, https://doi.org/10.3354/dao02039

[3] G. Kumar, K. Hummel, K. Noebauer, T.J. Welch, E. Razzazi-Fazeli, M. El-Matbouli, Proteome analysis reveals a role of rainbow trout lymphoid organs during Yersinia ruckeri infection process, Sci. Rep. 8 (2018) 13998, https://doi.org/10.1038/s41598-018-31982-6

[4] A. Wrobel, Structural and functional studies of the Yersinia ruckeri inverse autotransporters, Dissertation presented for the degree of Philosophiae Doctor, Faculty of Mathematics and Natural Sciences, University of Oslo (2019) No. 2072, ISSN 1501-7710

[5] D.P. Anderson, J.R. Nelson, Comparison of protection in rainbow trout (Salmo gairdneri) inoculated with and fed Hagerman redmouth bacterins, J. Fish. Res. Board. Canada. 31 (1974) 214216, https://doi.org/10.1139/f74-035

[6] K.A. Johnson, J.K. Flynn, D.F. Amend, Duration of immunity in salmonids vaccinated by direct immersion with Yersinia ruckeri and Vibrio anguillarum bacterins, J. Fish Dis. 5 (1982) 207-213, https://doi.org/10.1111/j.1365-2761.1982.tb00475.x

[7] S.G. Newman, J.J. Majnarich, Direct immersion vaccination of juvenile rainbow trout, Salmo gairdneri Richardson, and juvenile Coho Salmon, Oncorhynchus kisutch (Walbaum), with a Yersinia ruckeri Bacterin, J. Fish Dis. 5 (1982) 339-341, https://doi.org/10.1111/j.13652761.1982.tb00489.x

[8] M. Cossarini-Dunier, Protection against enteric redmouth disease in rainbow trout, Salmo gairdneri Richardson, after vaccination with Yersinia ruckeri bacterin, J. Fish Dis. 9 (1986) 27-33, https://doi.org/10.1111/j.1365-2761.1986.tb00976.x 
[9] J.K. Chettri, S. Deshmukh, L. Holten-Andersen, R.M. Jaafar, I. Dalsgaard, K. Buchmann, Comparative evaluation of administration methods for a vaccine protecting rainbow trout against Yersinia ruckeri O1 biotype 2 infections, Vet. Immunol. Immunopathol. 154 (2013) 42-47, https://doi.org/10.1016/j.vetimm.2013.04.001

[10] J.K. Chettri, R.M. Jaafar, J. Skov, P.W. Kania, I. Dalsgaard, K. Buchmann, Booster immersion vaccination using diluted Yersinia ruckeri bacterin confers protection against ERM in rainbow trout, Aquac. 440 (2015) 1-5, https://doi.org/10.1016/j.aquaculture.2015.01.027

[11] S. Deshmukh, P.W. Kania, J.K. Chettri, J. Skov, A.M. Bojesen, I. Dalsgaard, K. Buchmann, Insight from molecular, pathological, and immunohistochemical studies on cellular and humoral mechanisms responsible for vaccine-induced protection of rainbow trout against Yersinia ruckeri, Clinic. Vacc. Immunol. 20 (2013) 1623-1641, https://doi.org/10.1128/CVI.00404-13

[12] R.M. Jaafar, J.K. Chettri, I. Dalsgaard, A. Al-Jubury, P.W. Kania, J. Skov, K. Buchmann, Effects of adjuvant Montanide (TM) ISA 763 A VG in rainbow trout injection vaccinated against Yersinia ruckeri, Fish Shellfish Immunol. 47 (2015) 797-806, https://doi.org/10.1016/j.fsi.2015.10.023

[13] M. Henryon, P. Berg, N.J. Olesen, T.E. Kjær, W.J. Slierendrecht, A. Jokumsen, I. Lund, Selective breeding provides an approach to increase resistance of rainbow trout (Oncorhynchus mykiss) to the diseases redmouth disease, rainbow trout fry syndrome and viral haemorrhagic septicaemia, Aquac. 250 (2005) 621-636, https://doi.org/10.1016/j.aquaculture.2004.12.022

[14] T. Gjedrem, M. Baranski, Selective Breeding in Aquaculture: An Introduction, (2009) Springer Dordrecht Heidelberg London New York

[15] E.R. Verrier, M. Dorson, S. Mauger, C. Torhy, C. Ciobotaru, C. Hervet, N. Dechamp, C. Genet, P. Boudinot, E. Quillet, Resistance to rhabdovirus (VHSV) in rainbow trout: Identification of a major QTL related to innate mechanisms. PloS One 8 (2013) e55302, https://doi.org/10.1371/journal.pone.0055302

[16] G. Wiens, R.L. Vallejo, T.D. Leeds, Y. Palti, S. Hadidi, S. Liu, J.P. Evenhuis, T.J. Welch, C.E. Rexroad III, Genetic correlation between cold water disease resistance and spleen index in a domesticated population of rainbow trout: Identification of QTL on chromosome Omy19, PloS One 8 (2013) e75749, https://doi.org/10.1371/journal.pone.0075749 
[17] R.L. Vallejo, Y. Palti, S. Liu, J.P. Evenhuis, G. Gao, C.E. Rexroad 3rd, G.D. Wiens, Detection of QTL in rainbow trout affecting survival when challenged with Flavobacterium psychrophilum, Mar. Biotechnol. 16 (2014) 349-360, https://doi.org/10.1007/s10126-013-9553-9

[18] Y. Palti, C. Genet, M.C. Luo, A. Charlet, G. Gao, Y. Hu, C. Castaño-Sánchez, K. TabetCanale, F. Krieg, J. Yao, R.L. Vallejo, C.E. Rexroad 3rd, A first generation integrated map of the rainbow trout genome, BMC Genom. 12 (2011), https://doi.org/10.1186/1471-2164-12-180

[19] Y. Palti, G. Gao, S. Liu, M.P. Kent, S. Lien, M.R. Miller, C.E. Rexroad 3rd, T. Moen, The development and characterization of a $57 \mathrm{~K}$ single nucleotide polymorphism array for rainbow trout, Mol. Ecol. Resour 15 (2014) 662-672, https://doi.org/10.1111/1755-0998.12337

[20] T. Moen, J. Torgersen, N. Santi, W.S. Davidson, M. Baranski, J. Ødegård, S. Kjøglum, B. Velle, M. Kent, K.P. Lubieniecki, E. Isdal, S. Lien, Epithelial cadherin determines resistance to infectious pancreatic necrosis virus in Atlantic salmon, Genetics 200 (2015) 1313, https://doi.org/10.1534/genetics.115.175406

[21] I. Dalsgaard, L. Madsen, Bacterial pathogens in rainbow trout, Oncorhynchus mykiss (Walbaum), reared at Danish freshwater farms, J. Fish Dis. 23 (2000) 199-209, https://doi.org/10.1046/j.1365-2761.2000.00242.x

[22] K. Buchmann, An introduction to fish parasitological methods - classical and molecular techniques, (2007), Biofolia, Frederiksberg, Denmark.

[23] U. Khimmakthong, S. Deshmukh, J.K. Chettri, A.M Bojesen, P.W. Kania, I. Dalsgaard, K. Buchmann, Tissue specific uptake of inactivated and live Yersinia ruckeri in rainbow trout (Oncorhynchus mykiss): Visualization by immunohistochemistry and in situ hybridization, Microb. Pathog. 59-60 (2013) 33-41, https://doi.org/10.1016/j.micpath.2013.03.001

[24] A.M. Karami, A. Bani, M. Pourkazemi, M. Ghasemi, P.W. Kania, K. Buchmann, Comparative susceptibilities and immune reactions of wild and cultured populations of Caspian trout Salmo trutta caspius to VHSV, Dis. Aquat. Org. 128 (2018) 187-201, https://doi.org/10.3354/dao03231

[25] M.K. Purcell, G. Kurath, K.A. Garver, R.P. Herwig, J.R. Winton, Quantitative expression profiling of immune response genes in rainbow trout following infectious haematopoietic necrosis virus (IHNV) infection or DNA vaccination, Fish Shellfish Immunol. 17 (2004) 447-62, https://doi.org/10.1016/j.fsi.2004.04.017 
[26] S.H. Sugiura, K. Kelsey, R.P. Ferraris, Molecular and conventional responses of large rainbow trout to dietary phosphorus restriction, J. Comp. Physiol. B. 177 (2007) 461-72, https://doi.org/10.1007/s00360-007-0144-9

[27] H.C. Ingerslev, E.F. Pettersen, R.A. Jakobsen, C.B. Petersen, H.I. Wergeland, Expression profiling and validation of reference gene candidates in immune relevant tissues and cells from Atlantic salmon (Salmo salar L.), Mol. Immunol. 43 (2006)1194-201, https://doi.org/10.1016/j.molimm.2005.07.009

[28] M.K. Raida, K. Buchmann, Innate immune response in rainbow trout (Oncorhynchus mykiss) against primary and secondary infections with Yersinia ruckeri O1, Dev. Comp. Immunol. 33 (2009) 35-45, https://doi.org/10.1016/j.dci.2008.07.001

[29]M.H. Marana, J.K. Chettri, M. Brahe Salten, N. Emmervadt Bach-Olesen, P.W. Kania, I. Dalsgaard, K. Buchmann, Primary immunization using low antigen dosages and immunological tolerance in rainbow trout, Fish Shellfish Immunol. (2020) in press

[30] J. Xueqin, P.W. Kania, K. Buchmann, Comparative effects of four feed types on white spot disease susceptibility and skin immune parameters in rainbow trout, Oncorhynchus mykiss (Walbaum), J. Fish Dis. 35 (2012) 127-35, https://doi.org/10.1111/j.1365-2761.2011.01329.x

[31] M.K. Raida, K. Buchmann, Temperature-dependent expression of immune-relevant genes in rainbow trout following Yersinia ruckeri vaccination, Dis. Aquat. Org. 77 (2007) 41-52, https://doi.org/10.3354/dao01808

[32] J. Skov, J.K. Chettri, R.M. Jaafar, P.W. Kania, I. Dalsgaard, K. Buchmann, Effects of soluble immunostimulants on mucosal immune responses in rainbow trout immersion-vaccinated against Yersinia ruckeri, Aquaculture 49 (2018) 237-246, https://doi.org/10.1016/j.aquaculture.2018.04.011

[33] J.K. Chettri, J.A. Kuhn, R.M. Jaafar, P.W. Kania, O.S. Moller, K. Buchmann, Epidermal response of rainbow trout to Ichthyobodo necator: immunohistochemical and gene expression studies indicate a Th1-/Th2-like switch, J Fish Dis. 37 (2014) 771-783, https://doi.org/10.1111/jfd.12169

[34] M.K. Raida, K. Buchmann, Bath vaccination of rainbow trout (Oncorhynchus mykiss Walbaum) against Yersinia ruckeri: effects of temperature on protection and gene expression, Vaccine 26 (2008)1050-62, https://doi.org/10.1016/j.vaccine.2007.12.029 
[35] M.M. Olsen, P.W. Kania, R.D. Heinecke, K. Skjoedt, K.J. Rasmussen, K. Buchmann, Cellular and humoral factors involved in the response of rainbow trout gills to Ichthyophthirius multifiliis infections: Molecular and immunohistochemical studies, Fish Shellfish Immunol. 30 (2011) 859-69, https://doi.org/10.1016/j.fsi.2011.01.010

[36] J.K. Chettri, M.K. Raida, P.W. Kania, K. Buchmann, Differential immune response of rainbow trout (Oncorhynchus mykiss) at early developmental stages (larvae and fry) against the bacterial pathogen Yersinia ruckeri, Dev. Comp. Immunol. 36 (2012) 463-74, https://doi.org/10.1016/j.dci.2011.08.014

[37] J. Skov, P.W. Kania, L. Holten-Andersen, B. Fouz, K. Buchmann, Immunomodulatory effects of dietary beta-1,3-glucan from Euglena gracilis in rainbow trout (Oncorhynchus mykiss) immersion vaccinated against Yersinia ruckeri. Fish Shellfish Immunol. 33 (2012) 111-20, https://doi.org/10.1016/j.fsi.2012.04.009

[38] S.E. Keeling, C. Johnston, R. Wallis, C.L. Brosnahan, N. Gudkovs, W.L. McDonald, Development and validation of real-time PCR for the detection of Yersinia ruckeri, J Fish Dis. 35 (2012) 119-25, https://doi.org/10.1111/j.1365-2761.2011.01327.x

[39] K.J. Livak, T.D. Schmittgen, Analysis of relative gene expression data using real time quantitative PCR and the $2^{-\Delta \Delta C T}$ method, Methods 25 (2001) 402-408, https://doi.org/10.1006/meth.2001.1262

[40] C.L. Andersen, J.L. Jensen, T.F. Ørntoft, Normalization of real-time quantitative reverse transcription-PCR data: a model-based variance estimation approach to identify genes suited for normalization, applied to bladder and colon cancer data sets, Cancer Res. 64 (2004) 5245-50, https://doi.org/10.1158/0008-5472

[41] J.A. Yang, S.H. Lee, M.E. Goddard, P.M. Visscher, M. Peter, GCTA: A tool for genome-wide complex trait analysis, Am J Hum Genet. $88 \quad$ (2011) 76-82, https://doi.org/10.1016/j.ajhg.2010.11.011

[42] P.M. VanRaden, Efficient methods to compute genomic predictions, J. Dairy Sci. 91(2008) 4414-4423, https://doi.org/10.3168/jds.2007-0980 
[43] M.S.O. Brieuc, M.K. Purcell, A.D. Palmer, K.A. Naish, Genetic variation underlying resistance to infectious hematopoietic necrosis virus in a steelhead trout (Oncorhynchus mykiss) population, Dis. Aquat. Org. 117 (2015) 77-83, https://doi.org/10.3354/dao02933.

[44] R. Flore-Mara, F.H. Rodríguez, R. Bangera, J.P. Lhorente, R. Neira, S. Newman, J.M. Yáñez, Resistance against infectious pancreatic necrosis virus exhibits significant genetic variation and is not genetically correlated with harvest weight in rainbow trout (Oncorhynchus mykiss), Aquac. 479 (2017)155-160, https://doi.org/10.1016/j.aquaculture.2017.05.042

[45] G.M. Yoshida, R. Bangera, R. Carvalheiro, K. Correa, R. Figueroa, J.P. Lhorente, J.M. Yáñez, Genomic prediction accuracy for resistance against Piscirickettsia salmonis in farmed rainbow trout, G3 8 (2018) 719-726, https://doi.org/10.1534/g3.117.300499

[46] D. Marancik, G. Gao, B. Paneru, H. Ma, A.G. Hernandez, M. Salem, J. Yao, Y. Palti, G.D. Wiens, Whole-body transcriptome of selectively bred, resistant, control, and susceptible-line rainbow trout following experimental challenge with Flavobacterium psychrophilum, Front. Genet. 5 (2015) 453, https://doi.org/10.3389/fgene.2014.00453

[47] E.R. Fetherman, D.L. Winkelman, M.R. Baerwald, G.J. Schisler, Survival and reproduction of Myxobolus cerebralis-resistant rainbow trout introduced to the Colorado river and increased resistance of Age 0 progeny, PloS One 9 (2014) e96954, https://doi.org/10.1371/journal.pone.0096954

[48] F.E. Reyes-Lopez, J.S. Romeo, E. Vallejos-Vidal, S. Reyes-Cerpa, A.M. Sandino, L. Tort, S. Mackenzie, M. Imarai, Differential immune gene expression profiles in susceptible and resistant full-sibling families of Atlantic salmon (Salmo salar) challenged with infectious pancreatic necrosis virus (IPNV), Dev. Comp. Immunol. 53 (2015) 210-221, https://doi.org/10.1016/j.dci.2015.06.017

[49] Y. Palti, G. Gao, S. Liu, M.P. Kent, S. Lien, M.R. Miller, C.E. Rexroad 3rd, T. Moen, The development and characterization of a $57 \mathrm{~K}$ single nucleotide polymorphism array for rainbow trout, Mol. Ecol. Resour. 15 (2015) 662-672, https://doi.org/10.1111/1755-0998.12337

[50] M. Furlan, U. Rosani, S. Gambato, P. Irato, A. Manfrin, M. Mardirossian, P. Venier, A. Pallavicini, M. Scocchi, Induced expression of cathelicidins in trout (Oncorhynchus mykiss) challenged with four different bacterial pathogens, J Pep Sci. 24 (2018) e3089, https://doi.org/10.1002/psc.3089 
[51] D. Yang, A. Biragyn, D.M. Hoover, J. Lubkowski, J.J. Oppenheim, Multiple roles of antimicrobial defensins, cathelicidins, and eosinophil-derived neurotoxin in host defense, Annu. Rev. Immunol. 22 (2004) 181-215, https://doi.org/10.1146/annurev.immunol.22.012703.104603

[52] M. Zanetti, Cathelicidins, multifunctional peptides of the innate immunity, J Leukoc Biol Suppl 75 (2004) 39-48, https://doi.org/10.1189/jlb.0403147

[53] L. Tomasinsig, M. Zanetti, The cathelicidins-structure, function and evolution, Curr. Protein Pept. Sci. 6 (2005) 23-34, https://doi.org/10.2174/1389203053027520

[54] G.D. Wiens, R.L. Vallejo, Temporal and pathogen-load dependent changes in rainbow trout (Oncorhynchus mykiss) immune response traits following challenge with biotype 2 Yersinia ruckeri, Fish Shellfish Immunol. 29 (2010) 639-647, https://doi.org/10.1016/j.fsi.2010.06.010

[55] M.M. Monte, K. Urquhart, C.J. Secombes, B. Collet, Individual monitoring of immune responses in rainbow trout after cohabitation and intraperitoneal injection challenge with Yersinia ruckeri, Fish Shellfish Immunol. 55 (2016) 469-478, http://dx.doi.org/10.1016/j.fsi.2016.05.041 


\section{Tables}

\section{Table 1}

Primers and probes used for qPCR assays. All nucleotides are from 5' end (labeled with FAM) to 3' end (labeled with BHQ1). All the qPCR assays were optimized to have annealing temperature of $60^{\circ} \mathrm{C}$ and having efficiencies of $100 \% \pm 5 \% .{ }^{\mathrm{R}}$ indicates reference genes (housekeepers). ${ }^{\mathrm{MS}}$ indicates the qPCR assay targets both membrane bound and secreted forms. ${ }^{1}$ The $\alpha$ chain of IL-12 is common to the two isoforms of IL-12.

\section{Table 2}

Pearson's correlation coefficients between bacterial loads and expression of specific immune genes in different organs (Gill, Spleen, Liver) of trout at $7 \mathrm{dpc}$. Values above 0.5 and under -0.5 are shaded in grey. Please note the small number of pairs in the NCS groups of gill and liver.

\section{Table 3}

Heritability analysis of rainbow trout resistance towards Yersinia ruckeri 


\section{Figure legends}

Fig. 1. Morbidity curve following exposure of 1050 rainbow trout fry to Yersinia ruckeri.

Fig. 2. Bacterial load expressed as the number of gln $\mathrm{A}$ transcripts recorded (calculated as $2^{-\Delta \mathrm{Cq}}$ ) in rainbow trout organs (gill, spleen, liver) following exposure to live bacteria. Fish showing clinical signs (CS) at $7 \mathrm{dpc}$ compared to fish showing no clinical signs (NCS) at the same time point.

Surviving fish at $21 \mathrm{dpc}$ did not show transcripts of the $Y$. ruckeri glnA gene. Numbers above the brackets indicate the fold difference between the CS and NCS groups.

Fig. 3. Relative expression levels of immune relevant genes (all samples included) calculated as $2^{-}$ $\Delta \mathrm{Cq}$. For each tissue, the results were normalized to the gene having the lowest expression for that tissue. The number above the error lines indicates the number of samples with $\mathrm{Cq}$ values. The total number of samples in each organ was 90.

Fig. 4. Expression of immune relevant cytokine genes in rainbow trout organs (gill, spleen, liver) following exposure to live $Y$. ruckeri bacteria. Relative fold changes in relation to non-exposed time point controls for 1) fish showing clinical signs (CS) at $7 \mathrm{dpc}$ compared to 2) fish showing no clinical signs (NCS) at the same time point and 3) surviving fish at $21 \mathrm{dpc}$.

$\star$ : Significant differences $(\mathrm{p}<0.05)$ between bacterial exposed and non-exposed (control) groups (NCS, CS and surviving groups shown)

\#: Significant differences $(\mathrm{p}<0.05)$ between the NCS and CS groups at $7 \mathrm{dpc}$.

$\checkmark$ : Significant differences ( $\mathrm{p}<0.05$, non-parametric Mann-Whitney test) between bacterial exposed and control groups. 
Fig. 5. Expression of immune relevant effector molecule encoding genes in rainbow trout organs (gill, spleen, liver) following exposure to live Y. ruckeri bacteria. Relative fold changes in relation to non-exposed time point controls for 1) fish showing clinical signs (CS) at $7 \mathrm{dpc}$ compared to 2) fish showing no clinical signs (NCS) at the same time point and 3) surviving fish at $21 \mathrm{dpc}$.

$\star$ : Significant differences $(\mathrm{p}<0.05)$ between bacterial exposed and non-exposed (control) groups (NCS, CS and surviving groups shown)

\#: Significant differences $(\mathrm{p}<0.05)$ between the NCS and CS groups at $7 \mathrm{dpc}$.

\section{Fig. 6.}

Analysis of SNP composition of fish separated based on susceptibility/survival (Live/Dead) (A) and based on time until disease development (death) (B). The Manhattan plot indicates 4 loci for survival and 7 for time-to-morbidity but no major QTLs, suggesting that resistance against yersiniosis in rainbow trout is largely a polygenic trait. 


\begin{tabular}{|c|c|c|c|c|c|c|c|c|c|c|c|c|c|c|c|c|c|c|c|c|c|c|c|c|c|c|}
\hline 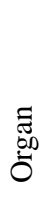 & 气 & 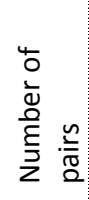 & $\tilde{O}$ & 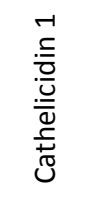 & 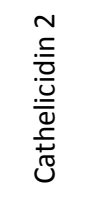 & $\begin{array}{l}\underline{\xi} \\
\text { 매 }\end{array}$ & 莒 & $\sum_{\underline{\mathrm{b}} 0}$ & to & $\stackrel{N}{=}$ & 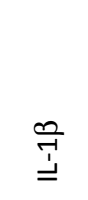 & 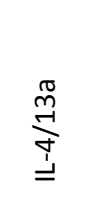 & $\stackrel{\varphi}{\stackrel{1}{=}}$ & $\stackrel{\infty}{\stackrel{\infty}{=}}$ & $\begin{array}{l}\stackrel{\circ}{\rightrightarrows} \\
\stackrel{1}{=}\end{array}$ & $\begin{array}{l}\stackrel{\sim}{I} \\
\stackrel{2}{=}\end{array}$ & $\begin{array}{l}\stackrel{N}{\stackrel{N}{ \pm}} \\
\stackrel{\vec{I}}{=}\end{array}$ & $\begin{array}{l}\stackrel{ }{I} \\
\stackrel{I}{=}\end{array}$ & 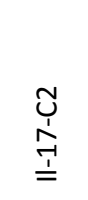 & $\stackrel{\underset{N}{\Perp}}{=}$ & $\sum_{\underline{u}}$ & 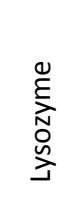 & $\frac{\pi}{4}$ & $\begin{array}{l}\infty \\
\stackrel{c}{0} \\
\qquad\end{array}$ & $\frac{\varrho}{\stackrel{U}{心}}$ & 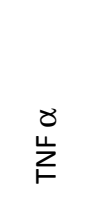 \\
\hline \multirow{2}{*}{$\overline{\overline{0}}$} & NCS & 3 & -0.25 & 0.94 & 0.96 & -0.64 & -1.00 & 0.94 & -0.08 & 1.00 & 1.00 & -0.11 & 0.99 & 1.00 & 0.84 & 0.62 & 0.77 & 0.91 & 0.47 & 1.00 & 0.12 & -0.84 & 0.68 & 0.00 & 1.00 & 0.88 \\
\hline & $\mathrm{CS}$ & 14 & 0.25 & -0.03 & 0.58 & 0.31 & 0.22 & 0.36 & 0.39 & -0.24 & -0.24 & -0.41 & 0.21 & 0.22 & 0.11 & 0.63 & 0.28 & 0.33 & 0.37 & -0.11 & 0.24 & 0.14 & 0.37 & 0.30 & -0.22 & 0.29 \\
\hline \multirow{2}{*}{ 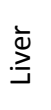 } & NCS & 3 & 0.00 & -0.59 & 0.89 & -0.81 & -0.52 & -0.66 & -0.81 & -0.98 & -0.08 & 0.77 & -0.30 & 0.35 & -0.77 & 0.75 & 0.00 & 0.59 & 0.50 & -0.55 & -0.51 & -0.11 & 0.70 & -0.43 & -0.84 & -0.13 \\
\hline & $\mathrm{CS}$ & 15 & -0.24 & 0.12 & 0.07 & 0.06 & 0.11 & 0.25 & 0.50 & 0.34 & -0.12 & 0.42 & 0.36 & 0.02 & 0.44 & 0.01 & -0.04 & 0.05 & 0.10 & -0.25 & 0.22 & 0.07 & 0.31 & 0.23 & 0.56 & -0.03 \\
\hline \multirow{2}{*}{$\begin{array}{l}\frac{\bar{d}}{\frac{0}{0}} \\
\frac{0}{n}\end{array}$} & NCS & 12 & 0.81 & -0.29 & -0.09 & -0.90 & -0.70 & -0.47 & -0.53 & 0.56 & 0.39 & -0.44 & 0.78 & 0.86 & -0.33 & 0.28 & -0.10 & 0.67 & 0.72 & 0.87 & 0.87 & -0.89 & 0.50 & 0.36 & -0.25 & -0.21 \\
\hline & $\mathrm{CS}$ & 15 & -0.25 & -0.03 & 0.07 & 0.21 & -0.37 & 0.01 & -0.12 & 0.20 & 0.12 & 0.34 & 0.17 & 0.29 & 0.21 & 0.30 & -0.68 & 0.76 & -0.20 & -0.64 & -0.64 & -0.11 & 0.07 & 0.32 & -0.50 & -0.21 \\
\hline
\end{tabular}

Tabel 2. Pearson's correlation coefficients between bacterial loads and expression of specific immune genes in different organs (Gill, Spleen, Liver) of trout at $7 \mathrm{dpc}$. Values above 0.5 and under -0.5 are shaded in grey. Please note the small number of pairs in the NCS groups of gill and liver. 
Table 3.

Analysis of heritability of rainbow trout resistance towards Yersinia ruckeri

\begin{tabular}{|l|l|l|}
\hline Factor & Estimate & SE \\
\hline Additive genetic variance & 0.047 & 0.014 \\
\hline Residual variance & 0.195 & 0.011 \\
\hline Phenotypic variance & 0.243 & 0.013 \\
\hline Heritability (observed scale) & 0.194 & 0.052 \\
\hline Heritability (underlying scale) & 0.306 & 0.082 \\
\hline Significance of polygenic effects & $P=3.23 \mathrm{e}-08$ \\
\hline
\end{tabular}




\section{Table 1}

Primers and probes used for qPCR assays. All nucleotides are from 5' end (labeled with FAM) to 3' end (labeled with BHQ1). All the qPCR assays were optimized to have annealing temperature of $60{ }^{\circ} \mathrm{C}$ and having efficiencies of $100 \% \pm 5 \% .{ }^{\mathrm{R}}$ indicates reference genes (housekeepers). ${ }^{\mathrm{MS}}$ indicates the qPCR assay targets both membrane bound and secreted forms. ${ }^{1}$ The $\alpha$ chain of IL-12 is common to the two isoforms of IL-12.

\begin{tabular}{|c|c|c|c|c|}
\hline $\begin{array}{l}\text { Gene } \\
\text { GenBank acc.no. }\end{array}$ & $\begin{array}{l}\text { Length } \\
\mathrm{Bp}\end{array}$ & $\begin{array}{l}\text { Primers } \\
\text { 5'end to 3'end }\end{array}$ & $\begin{array}{l}\text { Probes } \\
\text { 5'end to } 3 \text { 'end }\end{array}$ & References \\
\hline $\begin{array}{l}{ }^{R} \text { ARP } \\
\text { AY505012 }\end{array}$ & 106 & $\begin{array}{l}\text { Fwd: GAAAATCATCCAATTGCTGGATG } \\
\text { Rev: CTTCCCACGCAAGGACAGA }\end{array}$ & CTATCCCAAATGTTTCATTGTCGGCGC & [25] \\
\hline $\begin{array}{l}{ }^{R} \beta \text {-actin } \\
A B 196465\end{array}$ & 241 & $\begin{array}{l}\text { Fwd: ACATCAAGGAGAAGCTGTGCTAC } \\
\text { Rev: TACGGATGTCCACGTCACAC }\end{array}$ & сCTCTCTGGAGAAGAGCTACGAGCTG & $\begin{array}{l}\text { [26] Probe } \\
\text { this study }\end{array}$ \\
\hline $\begin{array}{l}{ }^{R} \text { ELF-1 } \alpha \\
\text { AF498320 } \\
\end{array}$ & 63 & $\begin{array}{l}\text { Fwd: ACCCTCCTCTTGGTCGTTTC } \\
\text { Rev: TGATGACACCAACAGCAACA }\end{array}$ & GCTGTGCGTGACATGAGGCA & [27] \\
\hline $\begin{array}{l}\text { C3.3 \& C3.4 } \\
\text { AF271080 / U61753 }\end{array}$ & 85 & $\begin{array}{l}\text { Fwd: ATTGGCCTGTCCAAAACACA } \\
\text { Rev: AGCTTCAGATCAAGGAAGAAGTTC }\end{array}$ & TGGAATCTGTGTGTCTGAACCCC & [28] \\
\hline $\begin{array}{l}\text { Cathelicidin 1A } \\
\text { AY382478 }\end{array}$ & 189 & $\begin{array}{l}\text { Fwd: TCTCTCGTCCTGGGGTT } \\
\text { Rev: GTTGTAGCGTGCTGATCTATG }\end{array}$ & TAATTGGTCGTCCTGGGGGTGG & [29] \\
\hline $\begin{array}{l}\text { Cathelicidin 2A } \\
\text { AY360356 }\end{array}$ & 135 & $\begin{array}{l}\text { Fwd: AAAGATTCCAAGGGGGGT } \\
\text { Rev: CAAAGGGTGTGTTGTGCTGT }\end{array}$ & GCTCTCGTCCTGGGTTTGGCTCC & [30] \\
\hline $\begin{array}{l}\text { IFN } \gamma 1 \text { and IFN } \gamma 2 \\
\text { FJ184374 / FJ184375 }\end{array}$ & 68 & $\begin{array}{l}\text { Fwd: AAGGGCTGTGATGTGTTTCTG } \\
\text { Rev: TGTACTGAGCGGCATTACTCC }\end{array}$ & TTGATGGGCTGGATGACTTTAGGA & [31] \\
\hline $\begin{array}{l}\text { IgDm } \\
\text { AY870262 }\end{array}$ & 304 & $\begin{array}{l}\text { Fwd: CAGGAGGAAAGTTCGGCATCA } \\
\text { Rev: CCTCAAGGAGCTCTGGTTTGGA }\end{array}$ & CCACACCACACAGACTCTGGCCCTGAA & [32] \\
\hline $\begin{array}{l}\text { IgDs } \\
\text { JQ003979 }\end{array}$ & 304 & $\begin{array}{l}\text { Fwd: TGGCACGCCAGGATTTGAC } \\
\text { Rev: TCAGAATTGAGTGAACGGACAGACA }\end{array}$ & CCACACCACACAGACTCTGGCCCTGAA & [32] \\
\hline $\begin{array}{l}\text { Ms IgM } \\
\text { S63348 / AH014877 }\end{array}$ & 72 & $\begin{array}{l}\text { Fwd: ACCCTCCTCTTGGTCGTTTC } \\
\text { Rev: TGATGACACCAACAGCAACA }\end{array}$ & TGATGACACCAACAGCAACA & [31] \\
\hline $\begin{array}{l}\text { MS IgT } \\
\text { AY870265 / AY870263 }\end{array}$ & 73 & $\begin{array}{l}\text { Fwd: AGCACCAGGGTGAAACCA } \\
\text { Rev: GCGGTGGGTTCAGAGTCA }\end{array}$ & AGCAAGACGACCTCCAAAACAGAAC & [31] \\
\hline $\begin{array}{l}\text { IL-1 } \beta \\
\text { AJ223954 }\end{array}$ & 91 & $\begin{array}{l}\text { Fwd: ACATTGCCAACCTCATCATCG } \\
\text { Rev: TTGAGCAGGTCCTTGTCCTTG }\end{array}$ & CATGGAGAGGTTAAAGGGTGGC & [31] \\
\hline $\begin{array}{l}\text { IL-2a } \\
\text { FJ571513 }\end{array}$ & 110 & $\begin{array}{l}\text { Fwd: ATGCAACACCACATCAGCAT } \\
\text { Rev: TGCCACGGCCCTACAAAAGA }\end{array}$ & TGCCACGGCCCTACAAAAGA & [29] \\
\hline $\begin{array}{l}\text { IL-4/13a } \\
\text { AB5743337 }\end{array}$ & 138 & $\begin{array}{l}\text { Fwd: ATCCTTCTCCTCTCTGTTGC } \\
\text { Rev: GAGTGTGTGTGTATTGTCCTG }\end{array}$ & CGCACCGGCAGCATAGAAGT & [33] \\
\hline $\begin{array}{l}\text { IL-6a } \\
\text { DQ866150 }\end{array}$ & 91 & $\begin{array}{l}\text { Fwd: ACTCCCCTCTGTCACACACC } \\
\text { Rev: GGCAGACAGGTCCTCCACTA }\end{array}$ & CCACTGTGCTGATAGGGCTGG & [34] \\
\hline $\begin{array}{l}\text { IL-8 isoforms } a, b, c, d \& e \\
\text { AY160982 to AY160986 }\end{array}$ & 69 & $\begin{array}{l}\text { Fwd: AGAATGTCAGCCAGCCTTGT } \\
\text { Rev: TCTCAGACTCATCCCCTCAGT }\end{array}$ & TTGTGCTCCTGGCCCTCCTGA & [34] \\
\hline $\begin{array}{l}\text { IL-10a } \\
\text { AB118099 }\end{array}$ & 70 & $\begin{array}{l}\text { Fwd: CGACTTTAAATCTCCCATCGAC } \\
\text { Rev: GCATTGGACGATCTCTTTCTTC }\end{array}$ & CATCGGAAACATCTTCCACGAGCT & [31] \\
\hline $\begin{array}{l}{ }^{1} \text { IL-12 } \alpha \text { chain } \\
\text { HE798148 }\end{array}$ & 84 & $\begin{array}{l}\text { Fwd: CAACGGAACACCACATTCAG } \\
\text { Rev: AGCCTGTAGTGAGGCAGCAT }\end{array}$ & TGCGTGTCTGAGGAACATCCG & [12] \\
\hline $\begin{array}{l}\text { IL-17A/F2a } \\
\text { AJ580842 }\end{array}$ & 158 & $\begin{array}{l}\text { Fwd: TCAAAAGCAACGTGTCGAAG } \\
\text { Rev: TCCCTCTGATTCCTCTGTGG }\end{array}$ & TATGCTGCTGGGCCTGACCA & [12] \\
\hline $\begin{array}{l}\text { IL-17c1 } \\
\text { CAW30792 }\end{array}$ & 138 & $\begin{array}{l}\text { Fwd: CTGGCGGTACAGCATCGATA } \\
\text { Rev: GAGTTATATCCATAATCTTCGTATTCGGC }\end{array}$ & CGTGATGTCCGTGCCCTTTGACGATG & [33] \\
\hline
\end{tabular}




\begin{tabular}{|c|c|c|c|c|}
\hline $\begin{array}{l}\text { IL-17c2 } \\
\text { CAW30793 }\end{array}$ & 134 & $\begin{array}{l}\text { Fwd: CTGGCGGTACAGCATCGATA } \\
\text { Rev: CAGAGTTATATGCATGATGTTGGGC }\end{array}$ & CGTGGTGTCCAGGCCCTTTAATGATG & [33] \\
\hline $\begin{array}{l}\text { IL-22 } \\
\text { AM748537 }\end{array}$ & 64 & $\begin{array}{l}\text { Fwd: ATGACCACCACCACAGCATT } \\
\text { Rev: ATTCCTTTCCCCTCCTCCAT }\end{array}$ & CTTTCCGCAAGAAGTTGTCCGAG & [35] \\
\hline $\begin{array}{l}\text { Lysozyme } \\
\text { X59491 }\end{array}$ & 188 & $\begin{array}{l}\text { Fwd: GAAACAGCCTGCCCAACT } \\
\text { Rev: GTCCAACACCACACGCTT }\end{array}$ & ATACCCAGGCCACCAACCGCAACAC & [36] \\
\hline $\begin{array}{l}\text { SAA } \\
\text { AM422446 }\end{array}$ & 79 & $\begin{array}{l}\text { Fwd: GGGAGATGATTCAGGGTTCCA } \\
\text { Rev: TTACGTCCCCAGTGGTTAGC }\end{array}$ & TCGAGGACACGAGGACTCAGCA & [37] \\
\hline $\begin{array}{l}\text { TCR- } \beta \\
\text { AF329700 }\end{array}$ & 73 & $\begin{array}{l}\text { Fwd: TCACCAGCAGACTGAGAGTCC } \\
\text { Rev: AAGCTGACAATGCAGGTGAATC }\end{array}$ & CCAATGAATGGCACAAACCAGAGAA & [31] \\
\hline $\begin{array}{l}\text { TGF- } \beta 1 a \\
\text { X99303 }\end{array}$ & 75 & $\begin{array}{l}\text { Fwd: TCTGAATGAGTGGCTGCAAG } \\
\text { Rev: GGTTTCCCACAATCACAAGG }\end{array}$ & CTGGAGAGGAGCAGGGATTCCAAT & [31] \\
\hline $\begin{array}{l}\text { TNF- } \alpha 1 \text { \& TNF- } \alpha 2 \\
\text { AJ277604 / AJ401377 }\end{array}$ & 75 & $\begin{array}{l}\text { Fwd: GGGGACAAACTGTGGACTGA } \\
\text { Rev: GAAGTTCTTGCCCTGCTCTG }\end{array}$ & GACCAATCGACTGACCGACGTGGA & [34] \\
\hline $\begin{array}{l}\text { gInA (Yersinia ruckeri) } \\
\text { AY333067 }\end{array}$ & 109 & $\begin{array}{l}\text { Fwd: TCCAGCACCAAATACGAAGG } \\
\text { Rev: ACATGGCAGAACGCAGATC }\end{array}$ & AAGGCGGTTACTTCCCGGTTCCC & [38] \\
\hline
\end{tabular}




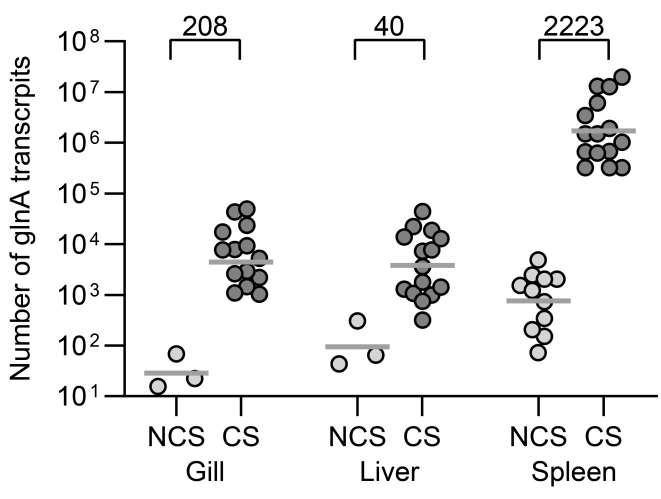



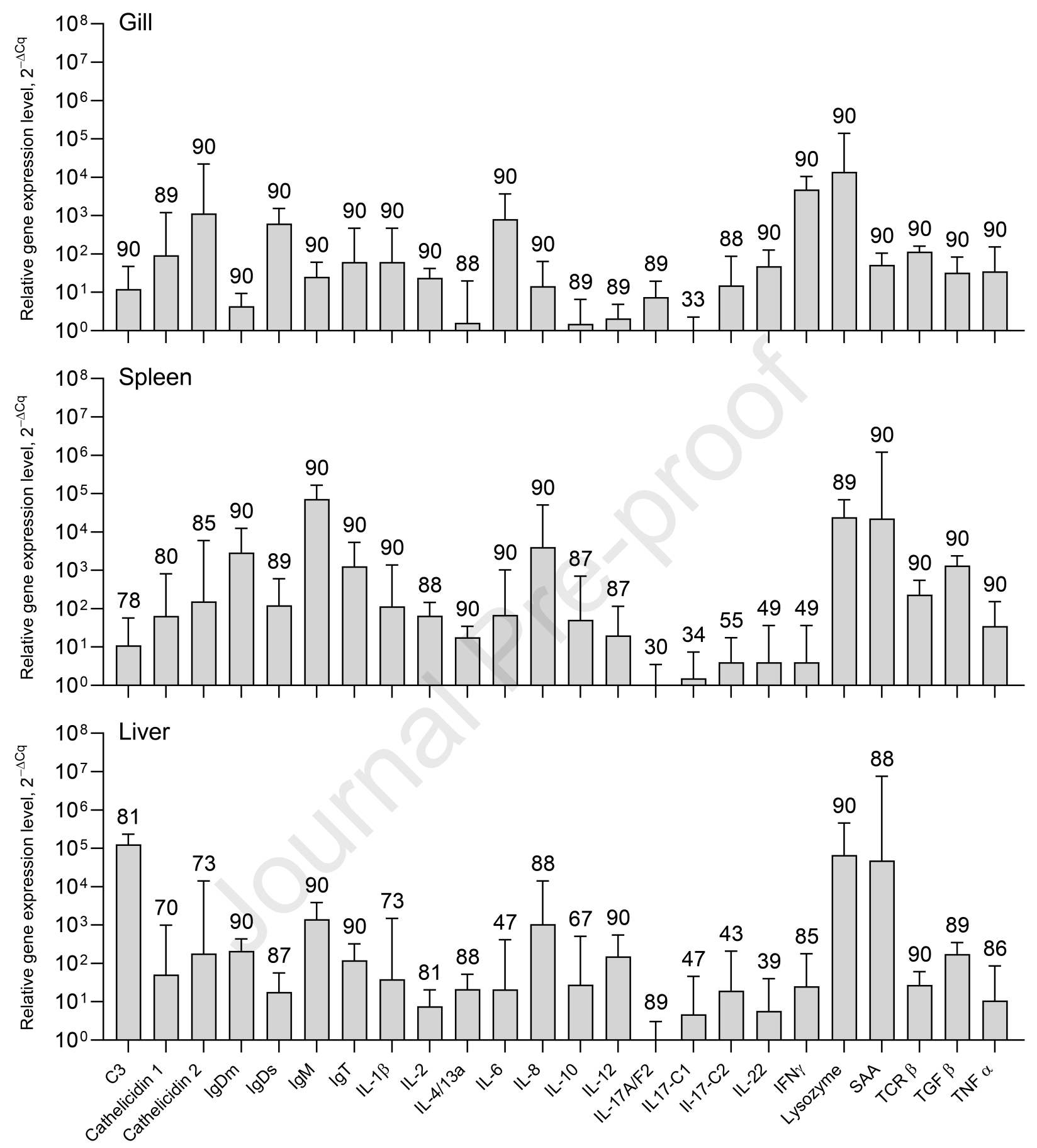

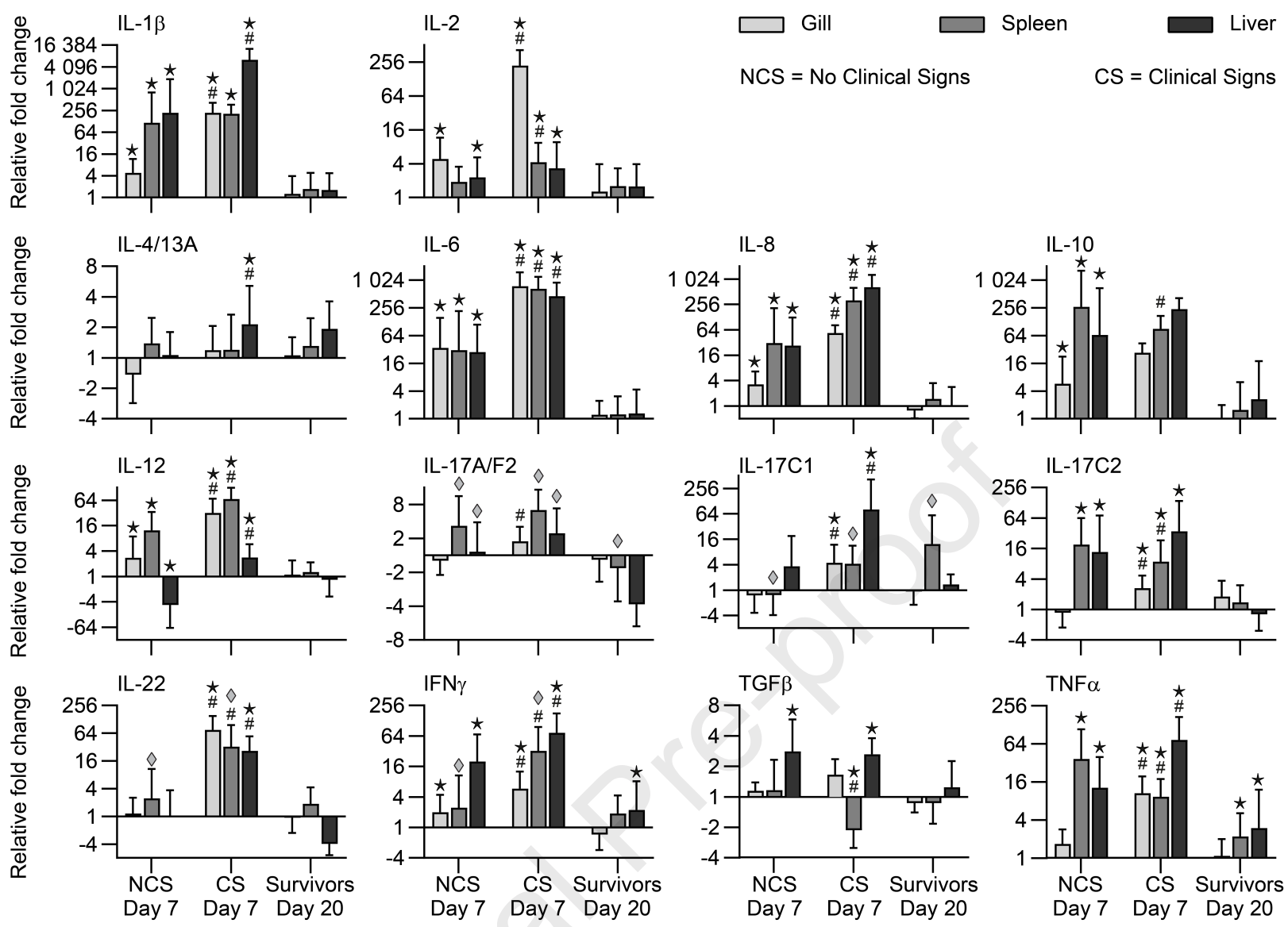

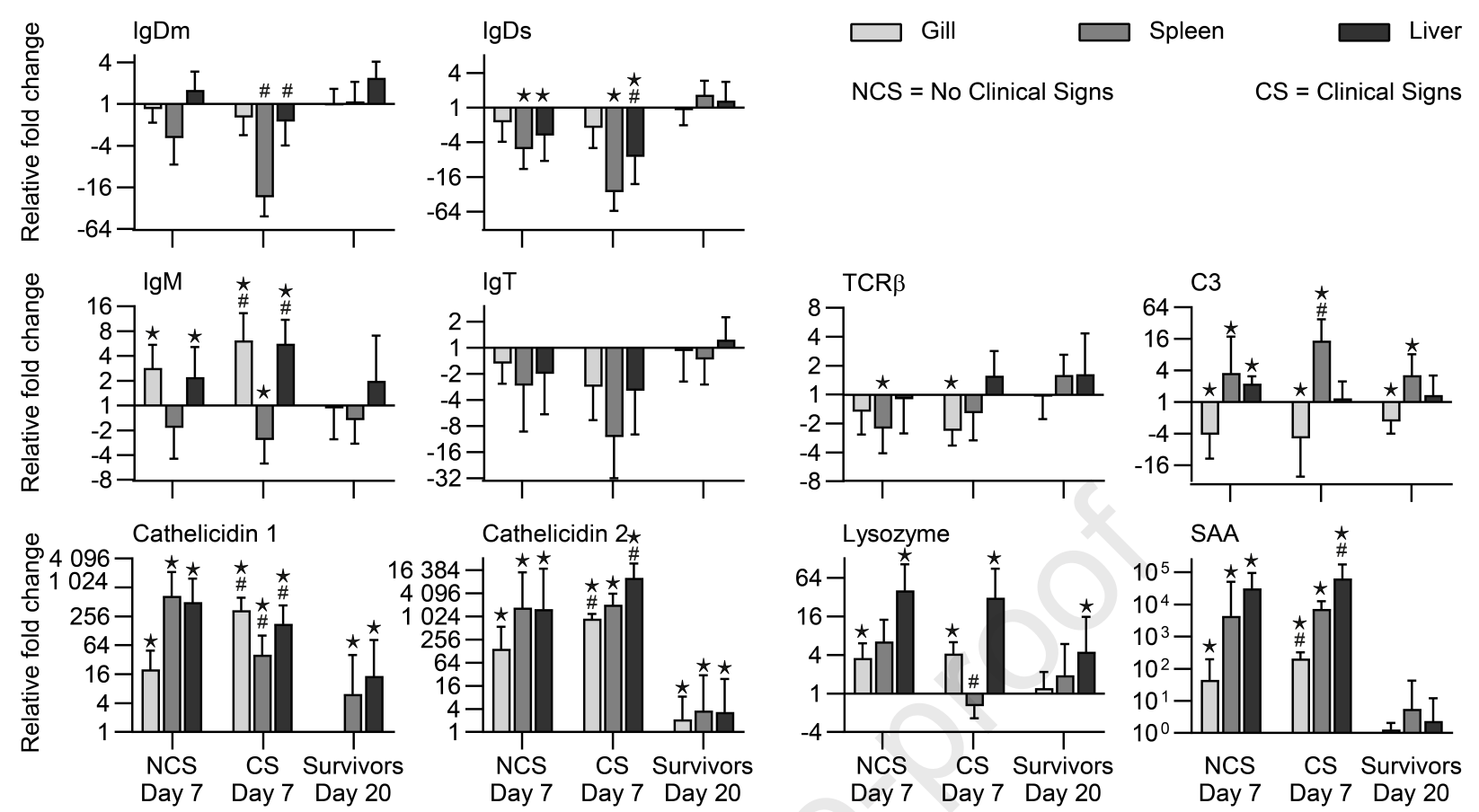

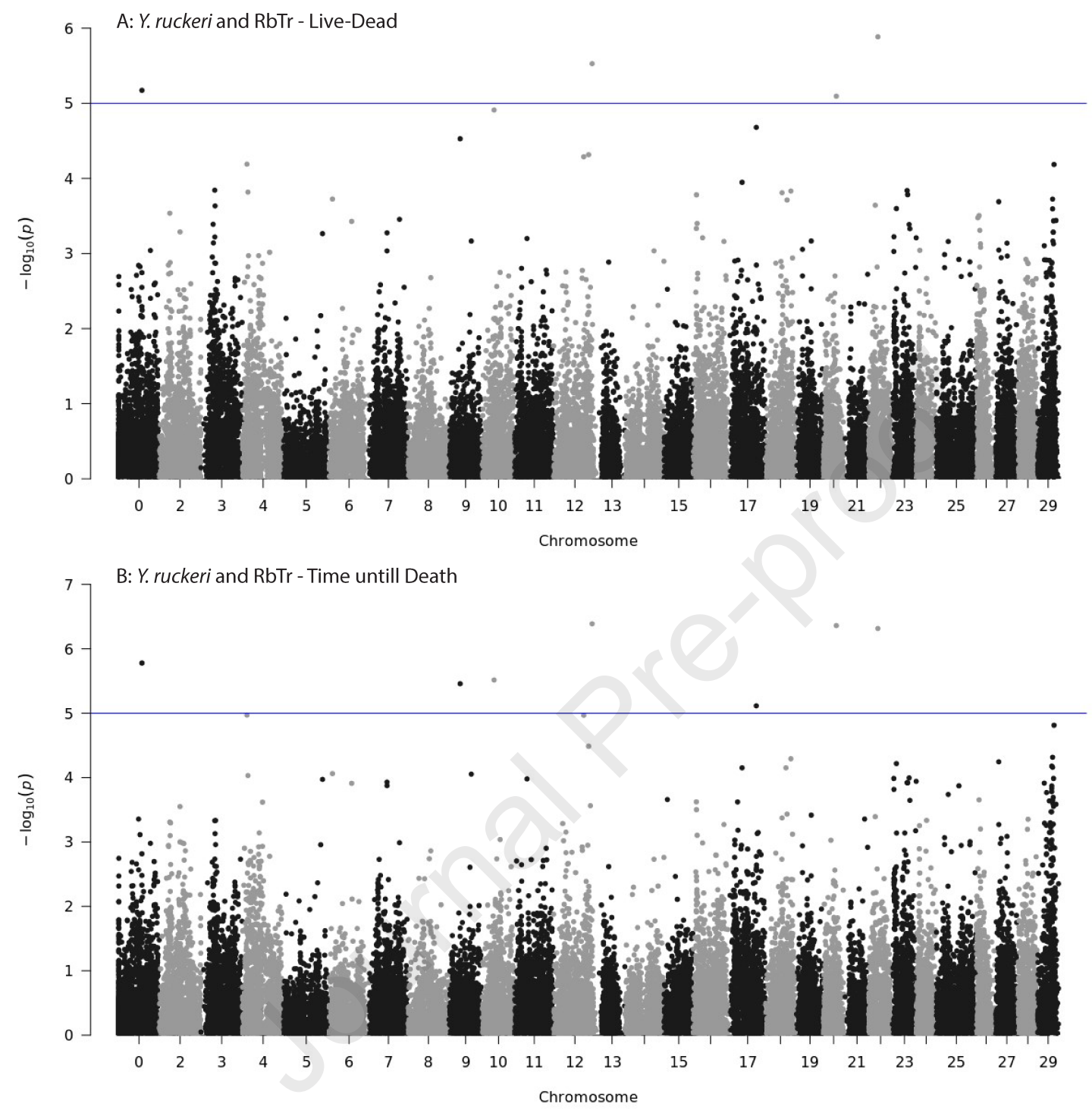


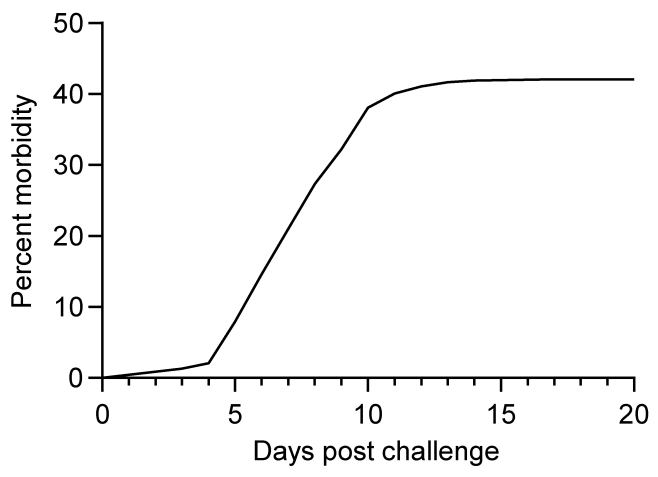


Highlights

SNP analyses of rainbow trout indicated that resistance against Yersinia ruckeri is a polygenic trait Expression of immune relevant genes different significantly beween resistant and susceptible trout Trout surviving the infection exhibited upregulated genes encoding innate effector molecules 